\title{
Marian Chace Foundation Lecture: Introduction of Dr. Lenore Hervey
}

\author{
Laura Downey
}

Published online: 4 March 2015

(C) American Dance Therapy Association 2015

When Lenore called me about 6 months ago to share with me that she was receiving this honor from the Marian Chace Foundation, I cried. I cried because I missed her and I also cried because I felt so deeply in my heart that she was so deserving of this honor. I was so touched to hear her joy, as well as her surprise, that she had been chosen. When she followed her news with the invitation to introduce her, my initial thought was how grateful I felt to be offered such an honor and to be part of this special experience with her. This was immediately followed with, "Well, who am $I$ to introduce anyone? Who am I to say something publicly about someone like Lenore-someone who I so highly regard as a dance/movement therapist and as a human being?" The weeks and months passed and I found my stress growing about what words I could possibly find to share something meaningful in the form of an introduction to her speech. I was finally able to take a step back and ask myself, "What would Lenore tell me?" I decided that she would tell me to say what I wanted to say and not worry about what might be the proper thing to say or what might be too silly.

I am honored beyond words to be introducing Dr. Lenore Hervey this evening. Lenore has an out-of-this-world curriculum vitae and here are a few examples. She was an educator in graduate dance/movement therapy programs for over 30 years; first, primarily at Antioch University New England then at Columbia College Chicago but she has taught in many other programs. Lenore received an American Dance Therapy Association (ADTA) Excellence in Education award for this work in 2011. She has facilitated workshops around the world in multiple languages. She published a book, Artistic Inquiry in Dance/Movement Therapy: Creative Alternatives for Research (2000), as well as numerous articles on research theory, her own research and evaluation, embodied ethical decision making, multicultural competency in dance/movement therapy and other topics in American and international

L. Downey $(\square)$

DCAT, Columbia College Chicago, 600 S. Michigan Ave, Chicago, IL 60605, USA

e-mail: Lmdowney@ hotmail.com; Ldowney@colum.edu 
journals. She has also been published in edited books such as Cruz and Berrol's (2012) Dance/Movement Therapists in Action: A Working Guide to Research Options. Lenore has advised many students on their theses and coached those topics from the depths of their beings into something researchable and meaningful to the student yet with value to the field. She continues to serve on thesis and dissertation committees in her retirement. Lenore has served on the ADTA Board of Directors as the Chair of the Research Subcommittee, Chair of the Education, Research and Practice Committee and Chair of the Ethics and Standards Committee. In addition, she was also a clinician! Lenore worked with adolescents, adults in inpatient psychiatric treatment, addictions, developmentally disabled, and elderly populations. No wonder she decided to retire a little early and travel the country with her husband-who is also her best friend.

As amazing as these accomplishments and contributions are to dance/movement therapy, they do not speak to the woman who is so incredible and has been such a wonderfully positive, supportive, compassionate and stable presence in my life for 13 years. This is what I want to share with you so that those of you who do not know her can get a glimpse of how special she is through the only frame of reference that I truly have-my own.

Lenore and I came to Columbia College Chicago the same year-she as a new full-time faculty member and I as a new graduate student. I can confess to feeling a little sharp around the edges and full of questions and expectations. I had been working in the corporate setting as an operations manager and trying out a path toward a doctorate in social psychology. I was raw, hurt, and needy. Among others in the faculty, Lenore was loving, guiding, and supportive. She was stable regardless of what I brought to the table. She met my questions with the skill of an educator but also challenged me to challenge myself with the love of an educator. She asked me the questions that led me to rediscover my gentleness, patience, and internal selfworth without telling me how I should do it or when it should happen.

And then, she became a mentor to me-guiding me into education, supporting me in my drive to find a way engage in research in dance/movement therapy, teaching me how to be in a role of knowing, yet holding the unknown and most recently helping me to find some kind of dual identity as a professional and also as a working mother. For those of you who watch Project Runway, Lenore became my Tim Gunn. She is not afraid to tell me when my outfit is ugly (translated to our work, when my run-on sentences are just beyond anything reasonable). As a matter of fact, I am pretty sure that when I was talking about the agony of my dissertation process last night, she told me to "stop complaining and make it work!"

Through modeling, Lenore has shown me what it truly means to not have to control the power, how to let my creative process guide me, how to trust my intuition, and how to follow my clients. Most importantly, she taught me how to ask the questions that lead my students to their own answers rather than the ones that I want them to find. One of the most important life lessons learned from Lenore is to be humble - to feel confident, but to be humble. Lenore will be the last person to list the many accomplishments on her curriculum vita, yet the wisdom that comes from her experiences is in everything that she does. 
Somewhere between teaching me to be a dance/movement therapist, guiding me into being an educator, and supporting me in my professional endeavors, Lenore became my friend-one of the most valuable and strongest presences in my life. I do not have words to say how important she is to me, but I have seen time and time again how she has just as greatly impacted her many students and colleagues over the time I have known her. She continues to support me and teach me, but now I hope that I am offering some of that in return.

What I hope that you take away from this introduction is that Lenore is "the real deal" - a talented teacher, a gifted therapist, a scholarly researcher, an integrated artist, a one of a kind mentor, and a treasured friend. Lenore embodies every day what we all love about the opportunity that dance/movement therapy offers our clients and us - the opportunity to have the courage to explore our creativity with our whole body, mind, and spirit with all of our vulnerabilities and all of our strengths. I am honored to introduce to you a real deal dance/movement therapist: Dr. Lenore Hervey.

\section{References}

Cruz, R., \& Berrol, C. (2012). Dance/movement therapists in action: A working guide to research options (2nd ed.). Springfield, IL: Charles C. Thomas.

Hervey, L. (2000). Artistic inquiry in dance/movement therapy: Creative alternatives for research. Springfield, IL: Charles C. Thomas.

\section{Laura Downey, BC-DMT, LPC, GL-CMA}

is part-time faculty, Research Coordinator and Assessment Coordinator in the Department of Creative Arts Therapies at Columbia College Chicago. She also recently joined the low residency Creative Arts Therapy program faculty with Pratt Institute. Laura has worked as a dance/movement therapist in inpatient and outpatient psychiatric and substance abuse programs, a rehabilitation program for individuals with traumatic brain injury and with veterans in a community based creative arts therapy program. Laura is Chair of the Research Sub-Committee and completing her dissertation on empathic reflection in clinical practice for a Doctorate of Education (Ed.D) in Counseling Psychology from Argosy University. Laura was awarded the Outstanding Achievement Award by the ADTA in 2013. 